\title{
THE DEVELOPMENT OF COMPOSITION AND CHARACTERIZATION OF BIODEGRADABLE HEMOSTATIC AND ABSORBABLE SPONGES FOR MEDICAL APPLICATION
}

\author{
BOHDANA PAVLIUK $^{1 *}$, MARIANA CHUBKA ${ }^{2}$, TARAS HROSHOVYI ${ }^{1}$ \\ ${ }^{I}$ Department of Pharmacy Management, Economics and Technology, "I. Horbachevsky” Ternopil National Medical \\ University, Ternopil, Ukraine \\ ${ }^{2}$ Department of Pharmacy, Educational Scientific Institute of Postgraduate Education, "I. Horbachevsky" Ternopil National \\ Medical University, Ternopil, Ukraine
}

*corresponding author: bohdana.vons@gmail.com

Manuscript received: September 2019

\begin{abstract}
The aim of this work was to develop and characterize a soft structured absorption sponge intended to stop bleeding. The medical sponge was prepared based on xenoderm water extract and adding chlorhexidine digluconate (1\%). The influence of excipients and their amounts on the quality of sponges (stability, degradation rate, morphological structure, percentage of water absorption, biological evaluation and haemostatic effect) were studied. The experimental results clearly confirmed that the medical sponges developed in this study could be suitable for haemostasis and can be used in medical practice.
\end{abstract}

\section{Rezumat}

Scopul acestei lucrări a fost să dezvolte și să caracterizeze un burete de absorbție destinat să oprească sângerarea. Buretele medical a fost preparat folosind extract apos de xenoderm și adăugându-se clorhexidină digluconat (1\%). S-a studiat influența excipienților și a cantităților acestora asupra calităţii bureților (stabilitate, rata de degradare, structura morfologică, procentul de absorbție a apei, evaluarea biologică și efectul hemostatic). Rezultatele experimentale au confirmat că bureții medicali dezvoltați în acest studiu sunt potriviți pentru hemostază și pot fi folosiți în practica medicală.

Keywords: biodegradation, haemostatic sponges, porous structure, xenoderm powder

\section{Introduction}

The development and study of absorbent haemostatic materials is important for both civilians and the military, as bleeding is present in any trauma and is one of the leading causes of death in war. Therefore, this fact stimulates the development of new haemostatic/ absorbent materials, sponges [3].

Medical sponge is a tool that has absorbent, antiseptic properties and can close the wound. According to the literature, sponge is a universal form that can be filled with the necessary active pharmaceutical ingredient, and accordingly, it can exhibit analgesic, anti-inflammatory, haemostatic, antiseptic and other actions [1]. For example, the haemostatic sponge not only prevents bleeding and large-scale blood loss, but also restores the integrity of damaged vessels, accelerates the tissues repair process of the epidermis and dermis $[1,7]$.

Haemostatic sponges are widely used in surgery due to their benefits since the dry sponge is characterized with absorption capacity. The mechanism of action of the sponges is the functioning of the porous structure. Platelets enter the coagulation cascade and transform soluble fibrinogen into insoluble fibrin, which stops bleeding [4]. When using a sponge directly on the wound surface, the bleeding stops by forming an artificial clot. Physiological formation of thrombin in the sponge is sufficient to stop bleeding due to its action on fibrinogen in the blood [9].

Today, many polymeric materials can be used to obtain medical sponges, including collagen and collagen fibres, cellulose and hemicellulose, gelatine, alginate and chitosan. Physical properties of collagen, gelatine and chitosan sponges promote clot formation and maintain its structure $[2,5,6]$.

Xenoderm powder is one of the main parts of the developed sponge. It is the biologically active material, which was obtained by the modern technology of cryo-preservation, lyophilization and grinding.

Nowadays, lyophilized xenodermo-implants are used as skin substitutes in the treatment of burns (I-II-III-IV degree), donor and scalp wounds, trophic ulcers, etc. [15]. Xenoderm powder is an active pharmaceutical ingredient used in the technology of new drugs, due to its enrichment with macro- and microelements, amino acids and other cellular elements that are necessary for skin regeneration. The presence of such dominant amino acids as histidine, arginine, valine, methionine, threonine and lysine prove its high metabolic and redox potential, which are required for the correction of regenerative processes $[8,15]$. By our own technology, 
based on xenoderm powder, a water extract was prepared, which became one of the main components of our medical sponges.

In this study, the medical sponge was prepared by the method of lyophilisation, using medical haemostatic gelatine and formaldehyde as matrix materials. We chose these components because of their economic benefits and accessibility. Among the aldehydes [1013], formaldehyde was selected due to its rapid reaction, low cost, availability, high solubility, and reaction with the large number of available amino groups that are present in the gelatine structure. However, formaldehyde reactions with proteins are heterogeneous and can cause toxic effects, so the concentration of aldehyde was chosen to be minimal. Preparation conditions were optimized by using pharmaco-technological indicators such as percentage of water absorption and degradation rate.

Therefore, the purpose of this work was to develop a haemostatic/absorption sponge and to study of its characteristics, to be able to use it in medical practice.

\section{Materials and Methods}

\section{Materials}

The crushed substrate of cryo-lyophilized xenoderm of the porcine skin (LCC Institute of Biomedical Technologies, Ukraine). Chlorhexidine digluconate solution 20\%, Formaldehyde, Gelatine (Sigma-Aldrich, USA).

\section{Animals}

The experiment was performed on adult male Wistar rats $(n=24)$, with mass $180 \pm 20 \mathrm{~g}$, that were randomly assigned into three treatment groups $(n=6)$ and control $(n=6)$. All animals were obtained from the vivarium of "I. Horbachevsky" National Medical University from Ternopil, Ukraine, and were kept under standard conditions $\left(20-22^{\circ} \mathrm{C}\right)$.

\section{Water extract preparation}

Pre-milled xenoderm powder of $1.0 \mathrm{~kg}$ was loaded into the extractor and infused at $38 \pm 0.5^{\circ} \mathrm{C}$ with vigorous stirring for 5 minutes every hour. The purified water was used as an extractant; its amount was calculated considering the water absorption coefficient of the powder (xenoderm - 4.5). The infusion was carried out during $14 \mathrm{~h}$ at the temperature $38 \pm 0.5^{\circ} \mathrm{C}$, after that the extract was drain through a double layer of gauze in the intermediate reservoir. Obtained water extract was loaded into collector, which gradually cooled to a temperature of $8-10^{\circ} \mathrm{C}$.

By this technology, we obtained a semi-finished product - xenoderm water extract, which is homogeneous with viscous consistency, white solution, with inherent odour and is the main component of medical sponges. Preparation of gelatine sponge

The gelatine with different concentrations - $0.5 ; 1.0$; $2.0 ; 3.0 ; 4.0 \%$, was used to prepare medical sponges. In the xenoderm water extract, the medical gelatine was left at $37^{\circ} \mathrm{C}$ for swelling and dissolution. Then the remainder of the xenoderm water extract was added to the gelatine solution by parts, with constant stirring until foam formation. To prepared solutions of xenoderm water extract with medical gelatine, the formaldehyde in the different concentration were added $(0.040 \%, 0.050 \%, 0.075 \%, 0.100 \%$ and $0.150 \%)$ to provide cross-linking. To the resulting mixtures it was added a $1 \%$ chlorhexidine digluconate solution [14]. The mixtures were foamed to form a stable foam that increased 2 - 3 times in volume. The resulting solution was poured out into the cooled aluminium moulds (size $15 * 7 \mathrm{~cm} / 100 \mathrm{~mL}$ ) and left for 2 - 3 hours at temperature $20-22^{\circ} \mathrm{C}$ to provide crosslink of the gelatine with formaldehyde and to form a framework. Thereafter, the solutions were frozen in liquid nitrogen and lyophilized during 18 - $20 \mathrm{~h}$ (7 $8 \mathrm{~h}-$ at temperature $-30 \pm 0.5^{\circ} \mathrm{C}, 4-5 \mathrm{~h}-$ at temperature $+30 \pm 0.5^{\circ} \mathrm{C}$, and $6-7 \mathrm{~h}-$ at temperature $+35 \pm 0.5^{\circ} \mathrm{C}$ ). The finished dry product (medical sponge) was cut into plates of various sizes and packed in parchment bags.

\section{Morphological observation}

The appearance and pore structure of the medical sponges were observed by optical microscopy method (microscope Nicon Eclipse CI-E).

Water absorption determination

To the flat-bottomed cup (pre-heated to $37 \pm 1^{\circ} \mathrm{C}$ ) it was added a simulation solution containing $8.398 \mathrm{~g} / \mathrm{L}$ sodium chloride and $0.278 \mathrm{~g} / \mathrm{L}$ anhydrous calcium chloride (the given proportion of ion content equal to the amount in human serum).

A piece of dry sponge $1 \times 1 \mathrm{~cm}^{2}\left(\mathrm{X}_{0}\right)$, pre-weighed, immersed in a simulation solution for 10 minutes. Then the sponge removed from the solution and, after the surface wipe with the filter paper - weighed $\left(\mathrm{X}_{1}\right)$. Water absorption (\%) calculated:

Water absorption $(\%)=\left(\mathrm{X}_{1}-\mathrm{X}_{0}\right) / \mathrm{X}_{0} \times 100 \%$, where $\mathrm{X}_{0}$ - the mass of the sponge before absorption; $\mathrm{X}_{1}$ - the mass of the sponge after absorption.

The experiment carried out in parallel at two different temperatures: room temperature $\left(25 \pm 3^{\circ} \mathrm{C}\right)$ and in thermostat $\left(37^{\circ} \mathrm{C}\right)$ with subsequent interpretation of the results.

\section{In vitro degradation}

Degradation can be determined by immersing a piece of sponge $\left(1 \times 1 \mathrm{~cm}^{2}\right)$ in phosphate buffer solution (PBS) with $\mathrm{pH} 7.4$ for $24 \mathrm{~h}$. The tests carried out at room temperature $\left(25 \pm 3^{\circ} \mathrm{C}\right)$ and in a thermostat $\left(37^{\circ} \mathrm{C}\right)$, than followed by a comparison of the test results. After 24 hours, the sponge was re-dried and the change in the sponge mass was calculated. In vitro degradation was calculated by the formula:

In vitro degradation $(\%)=\left(\mathrm{X}_{\mathrm{f}}-\mathrm{X}_{\mathrm{s}}\right) / \mathrm{X}_{\mathrm{s}} \times 100 \%$ where $X_{f}$ - the final mass of the sponge after drying; $\mathrm{X}_{\mathrm{s}}$ - the initial mass of the sponge before immersion. 
Study of $p H$ change

The change in the $\mathrm{pH}$ solution during degradation of the sponge was determined after 10, 30, $60 \mathrm{~min}, 12,24$, 36,48 and $72 \mathrm{~h}$ using a brand $\mathrm{pH}-$ meter «MI-150». Haemostatic study on the femoral artery model in rats Experimental studies were conducted at the Central Scientific Laboratory of "I. Horbachevsky" National Medical University, Ternopil, Ukraine. Animals were divided into 4 groups, 6 animals in each group (I control group, II - pathology + sponge xenoderm, III - pathology + gelatine sponge, IV - pathology + collagen sponge). The femoral artery was cut with a disposable scalpel, with anaesthesia (sodium thiopental). After bleeding for $5 \mathrm{~s}$, a piece of sponge $1 \times 1 \mathrm{~cm}^{2}$ was used to close the wound and stop the bleeding. Animal behaviour control was performed within 7 days before and after the experiment.

All manipulations were performed in accordance with the general ethical principles of animal experimentation, governed by the provisions of the European Convention on the Protection of Vertebrate Animals, Used for Research and Other Scientific Purposes and with the Law of Ukraine «On the Protection of Animals from
Cruelty» (from 15.12.2009 No 1759-VI), and EU Directive 2010/10/63 EU on animal experiments. Statistical Analysis

The statistical processing of the obtained results was performed by the methods of variation statistics, with using the Student's t-test with computer programs MS Excel 2010. Statistical comparison of multiple groups was performed by the one-way ANOVA, followed by the Bonferroni test using GraphPad Prism version 5.00 (GraphPad Software, Inc).

\section{Results and Discussion}

The effect of gelatine concentration on the percentage of water absorption in sponges

In the finished dry product (medical sponge), water absorption was determined; the test results are shown in Figure 1.

Based on the results of studies, it can be concluded that the absorption of water by sponges increased with the gelatine concentration. The maximum of water absorption was observed in sponges with a gelatine concentration of $2 \%$.

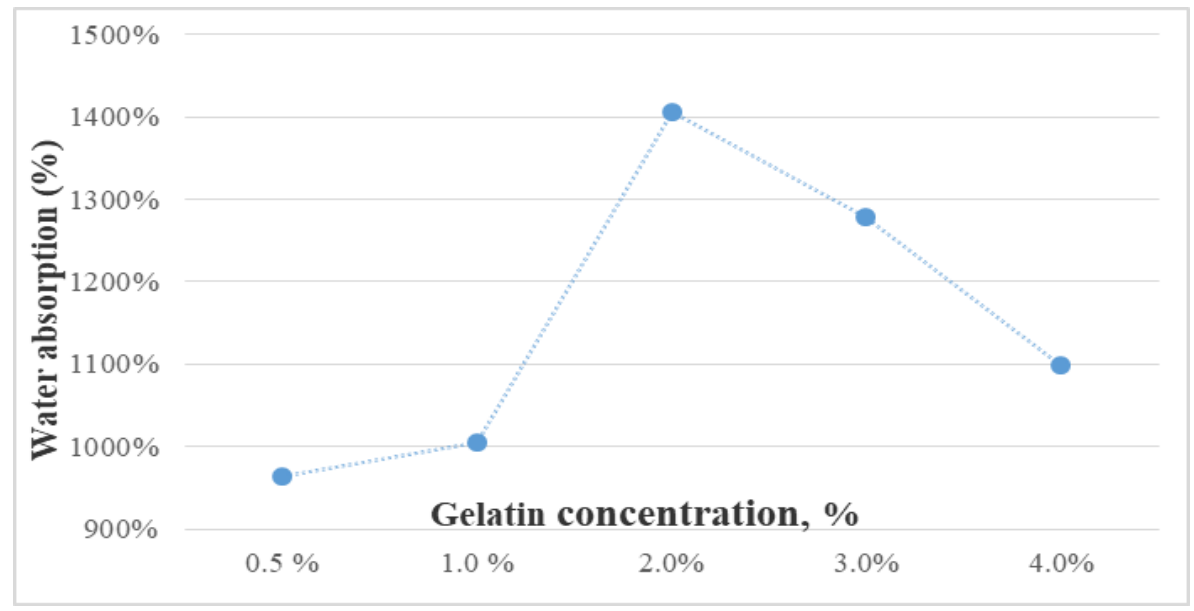

Figure 1.

Water absorption (\%) during the gelatine concentration changing

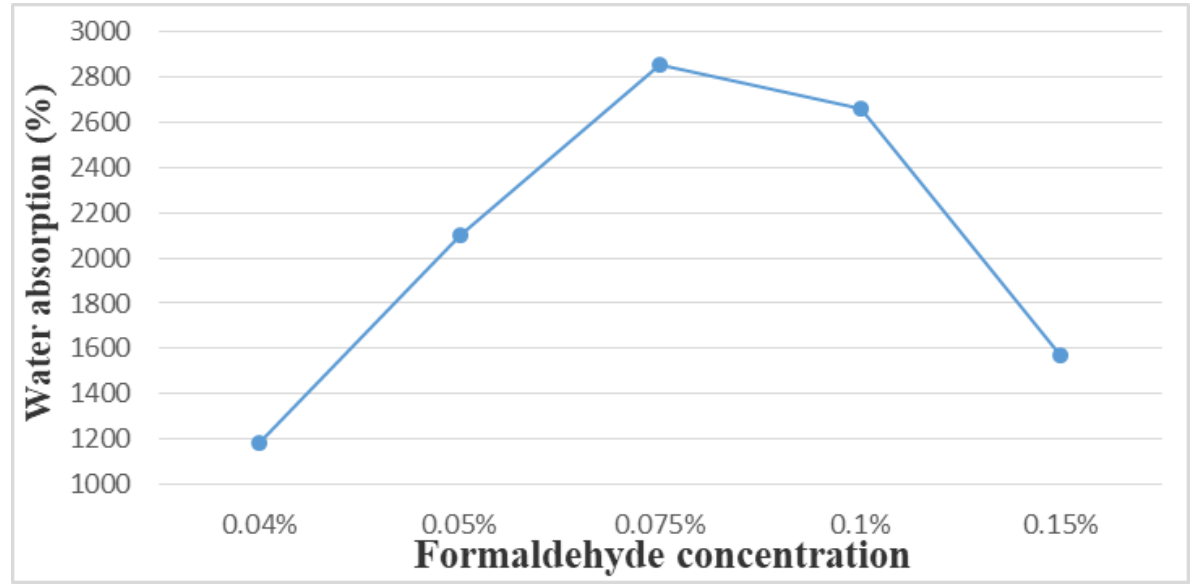

Figure 2.

Water absorption (\%) during the formaldehyde concentration changing 
The effect of formaldehyde concentration on the percentage of water absorption in sponges

To increase the percentage of water absorption and to improve the pharmacological quality indicators, it was decided to introduce formaldehyde. The sponges were prepared with $2 \%$ solution of gelatine in the xenoderm water extract. The formaldehyde concentration was $0.040 \%, 0.050 \%, 0.075 \%, 0.100 \%$ and $0.150 \%$, respectively. The qualitative characterization of the obtained sponges was selected by the percentage of water absorption that most fully characterizes the efficiency of the sponges. The effect of formaldehyde concentration on the characteristics of the obtained sponges is presented in Figure 2. The percentage of water absorption of the sponge reached its maximum value at a formaldehyde concentration of $0.075 \%$, and then, with a further increasing formaldehyde, sharply decreased. Because of the too high concentration of formaldehyde high degree of crosslinking of the sponge occurred. This leads to increase sponge pore tightness and therefore to decrease water absorption percentage. Morphology Studies

Macroscopic examination showed that the developed sponge is white, structured and porous. Optical microscopy method using a microscope Nicon Eclipse CI-E showed a clear sponge structure, as well as the presence of a large number of pores equally distributed throughout the sponge structure.
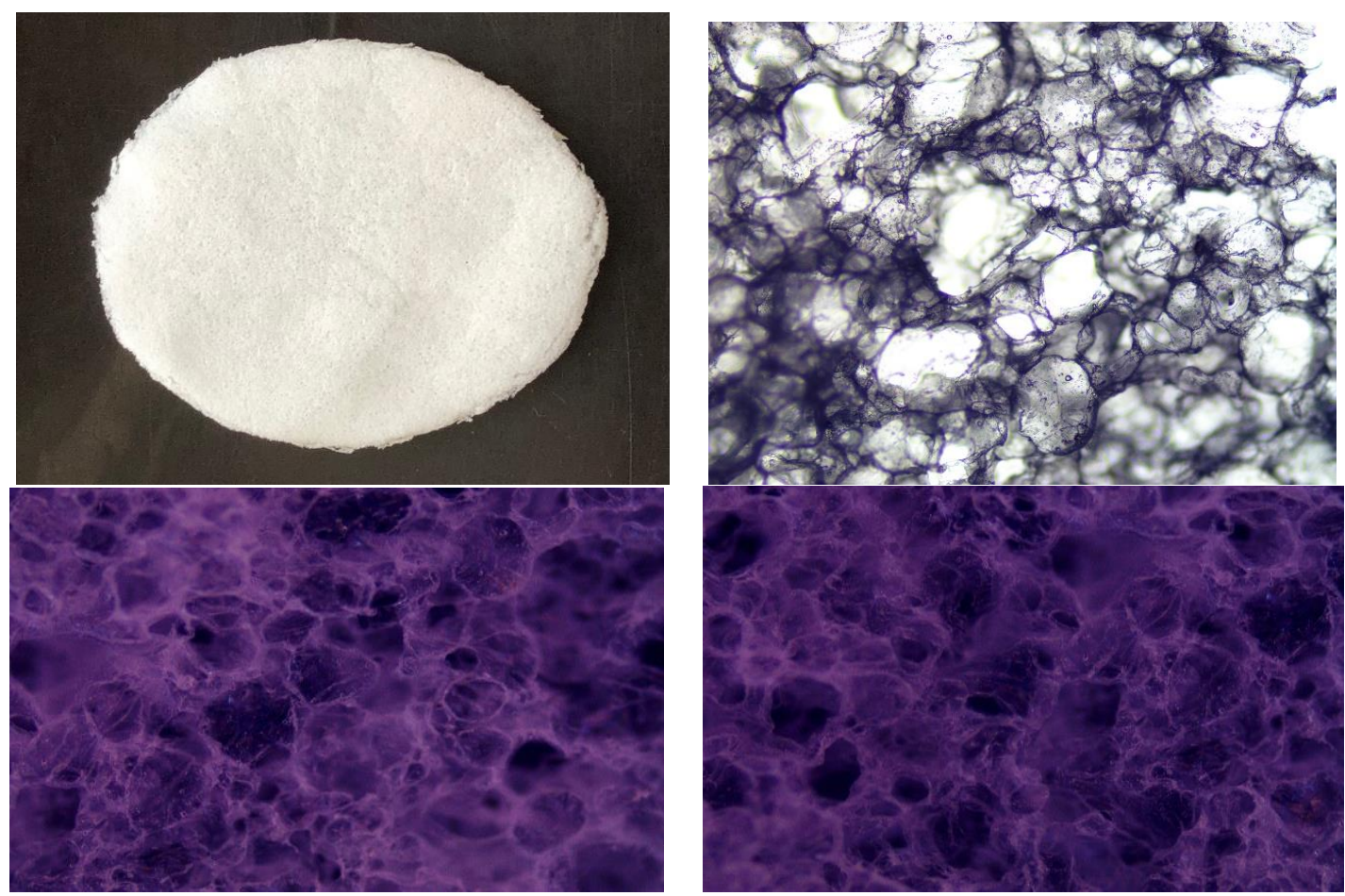

Figure 3.

Appearance of medical sponges based on xenoderm water extract with $2 \%$ gelatine and $1 \%$ chlorhexidine digluconate (microscope Nicon Eclipse CI-E)

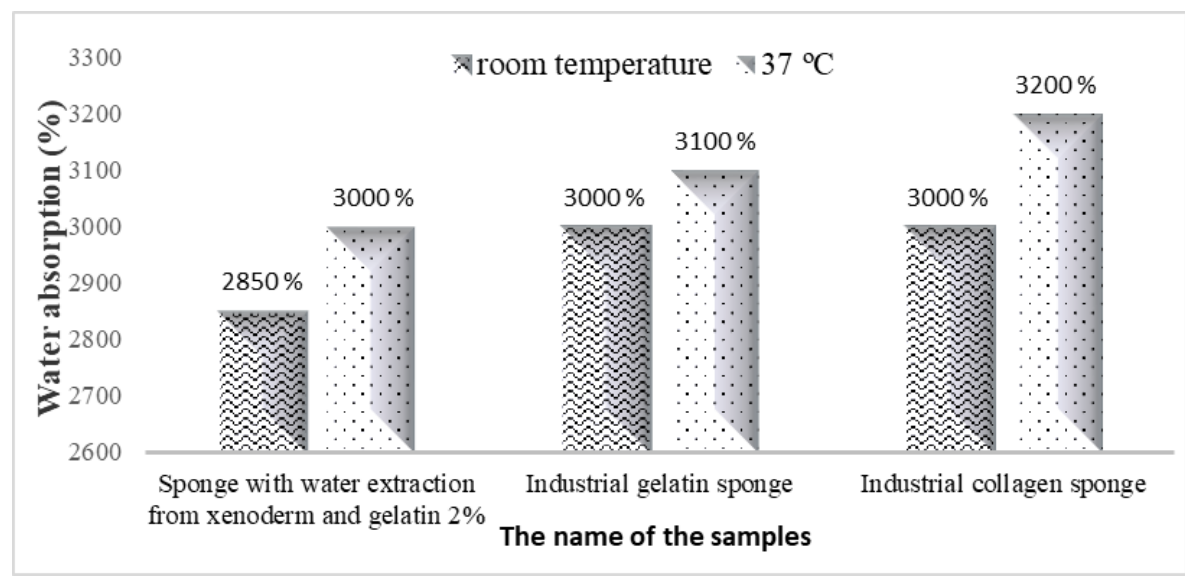

Figure 4.

Water absorption rate of different sponges 


\section{Water absorption determination}

Water absorption (\%) allows to estimate the rate of absorption, since the greater the value of absorption rate $(\%)$, the faster and more the sponge can absorb exudate (blood). The value of this indicator was determined in the simulation solution, which is the most similar in $\mathrm{pH}$ and ionic composition to blood plasma and interstitial fluid. Figure 4 shows the results of determining the rate of water absorption by different sponges in $10 \mathrm{~min}$. For comparative testing, a developed sponge based on xenoderm water extraction with $2 \%$ gelatine and $1 \%$ chlorhexidine digluconate, compared to industrial production gelatine and collagen sponges were selected. As a result of the tests, it was found that the value of the water absorption (\%) for gelatine sponges based on xenoderm water extraction at room temperature $\left(20-22^{\circ} \mathrm{C}\right)$ and at temperature of $37^{\circ} \mathrm{C}$ are $2800-2850 \%, 3000-3100 \%(n=5)$.

The value of the water absorption index of industrial gelatine sponges at room temperature $\left(20-22^{\circ} \mathrm{C}\right)$ and at $37^{\circ} \mathrm{C}$ are $3000-3100 \%$ and $3200-3300 \%(n=5)$, and industrial collagen sponges at these temperatures are $3000-3100 \%, 3100-3200 \%(n=5)$.
In vitro degradation

The degree of degradation determines the stability of the biodegradable material, since the value of the degradation index (\%) allows to estimate the time of complete dissolution of the sponge.

The degradation rate for a sponge based on xenoderm water extraction with $2 \%$ gelatine and $1 \%$ chlorhexidine digluconate at room temperature is $26 \pm 3 \%$ and at $\left.37^{\circ} \mathrm{C}-41 \pm 3 \%\right)(\mathrm{n}=5)$. The complete dissolution time at room temperature $\left(25 \pm 3^{\circ} \mathrm{C}\right)$ and in the thermostat $\left(37^{\circ} \mathrm{C}\right)$ are 72 and $48 \mathrm{~h}$, respectively $(\mathrm{n}=5)$.

The value of the studied indicator for gelatine sponge industrial production is $86 \%$ at room temperature $( \pm 3 \%)(\mathrm{n}=5)$. The complete dissolution time of the gelatine sponge at room temperature $\left(25 \pm 3^{\circ} \mathrm{C}\right)$ and in the thermostat $\left(37^{\circ} \mathrm{C}\right)$ are 36 and $22 \mathrm{~h}$, respectively $(\mathrm{n}=5)$.

The percentage degradation of collagen sponge industrial production at room temperature is $48 \pm 3 \%)(\mathrm{n}=5)$, and the time of complete dissolution at room temperature $\left(25 \pm 3^{\circ} \mathrm{C}\right)$ and in thermostat $\left(37^{\circ} \mathrm{C}\right)$ are 48 and $22 \mathrm{~h}$, respectively $(\mathrm{n}=5)$.

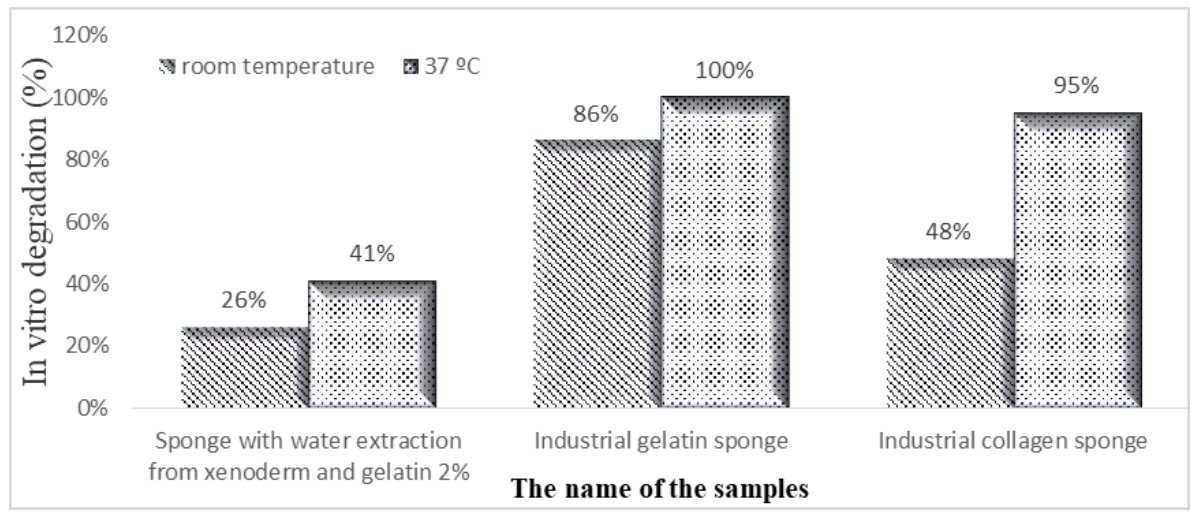

Figure 5.

Degradation of samples in room temperature and physiological condition $\left(37^{\circ} \mathrm{C}\right)$

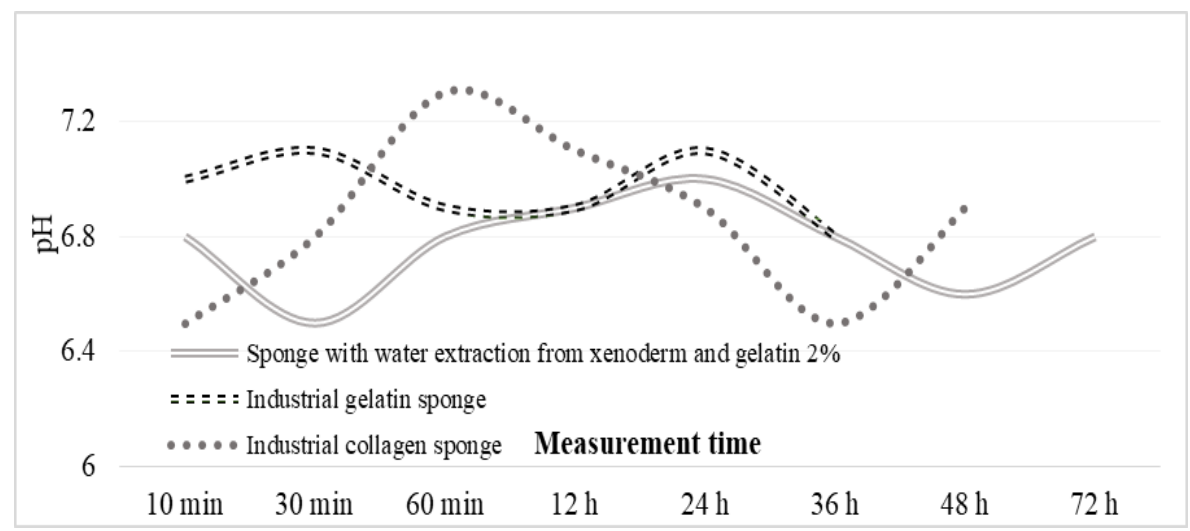

Figure 6.

Changes in $\mathrm{pH}$ during in vitro degradation of sponges

\section{Study of pH change}

The $\mathrm{pH}$ value is important because it characterize the stability of sponges. The neutral value of $\mathrm{pH}$ during degradation indicates that there is no excess of aldehydes or other toxic substances, which can adversely affect the body. All three specimens of the sponges showed 
that they did not change the $\mathrm{pH}$ during their degradation and kept it within the neutral range (Figure 6).

The results of the experiment on animals

Figure 7 shows the results of an animal experiment and Figure 8 shows a model of femoral artery injury, the smaller the haemostatic time, the better the ability to thicken the sponge in vivo. In each case, the bleeding stopped within $50-70 \mathrm{~s}$, excepting control group. According to the statistical analysis shown in the Figure 7, the haemostatic sponge based on xenoderm water extract with $2 \%$ gelatine and $1 \%$ chlorhexidine digluconate has a good clotting ability and stops bleeding during $61 \mathrm{~s}$.

The industrial haemostatic collagen sponge stops bleeding during $70 \mathrm{~s}$ and industrial gelatine sponge $58 \mathrm{~s}$. Regarding to the control group of animals, the bleeding lasted for $120 \mathrm{~s}$, after this period, the bleeding was stopped using the haemostatic material to prevent death of animals.

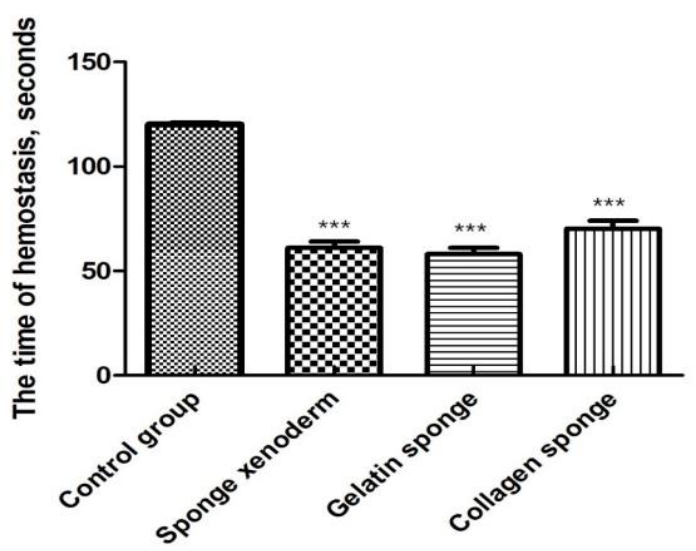

Figure 7.

The time of haemostasis using different sponges on the rat's femoral artery model

(Data are presented as mean \pm SEM. Statistical analysis was carried out by one-way ANOVA: $* * * \mathrm{p}<0.0001$ vs. control)

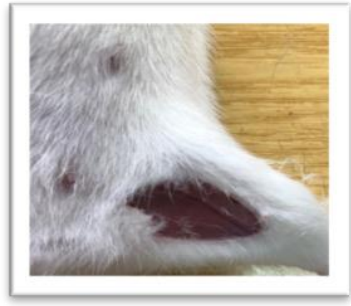

(1)

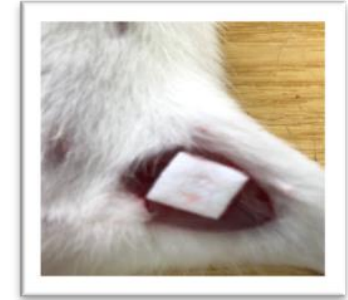

(2)
Figure 8.

Photographs of (1) the rat's femoral artery model;

(2) the haemostatic effect of xenoderm water extract sponge with $2 \%$ gelatine and $1 \%$ chlorhexidine digluconate

The industrial gelatine sponge and xenoderm water extract medical sponge stopped bleeding better and faster, fixed on the wound surface, as well as kept the stable structure of the sponge. Regarding the industrial collagen sponge, it was detected that they absorb and stop the bleeding more slowly (70 s); however, they do not retain structures and fixed on the wound surface. According to the results of the animal experiment, a higher clotting ability time in vivo is showed, shortening haemostatic time. After the experiment, on the $7^{\text {th }}$ day, the edges of the wound were completely tightened in all cases.

Also it was observed, that the absorption rate of haemostatic sponge with xenoderm water extract and industrial gelatine sponge were better compared to comparison industrial collagen sponge. In the case of the industrial collagen sponge, it was observed that blood leak from the pore structure, which was absent when using the other sponges in the experiment. This can be due to the poor flexibility of the collagen sponges, while the gelatine incorporation makes them more flexible, structured, and adhesive. That increase haemostatic effect, due to the presence of a porous framework.

\section{Conclusions}

The efficiency, cost-effectiveness, accessibility, and ease of use of medical/haemostatic sponges in medicine are important factors in technology of their creation.

Haemostatic sponges were prepared based on xenoderm water extract by using the lyophilization method. Gelatine and aldehyde (formaldehyde) are used as excipients, which form a framework that easily adapts the biostability and mechanical properties of the sponge when interacting. The developed sponges are structured, porous, with equally distributed pores of different sizes.

Sponges showed a similar ability to coagulate blood, on a level with industrial production of similar action. This confirmed the possibility of using xenoderm water extract, which enriched with amino acids, macroand microelements in the technology of haemostatic sponges.

\section{Conflict of interest}

The authors declare no conflict of interest.

\section{References}

1. Deng AH, Chen AZ, Wang SB, Porous nanostructured poly-l-lactide scaffolds prepared by phase inversion using supercritical $\mathrm{CO}_{2}$ as a nonsolvent in the presence of ammonium bicarbonate particles. J Supercrit Fluids., 2013; 77: 110-116.

2. Haripriya $S$, Ajitha $P$, Perforation repair using absorbable collagen sponge and biodentine. J Clinic Diagn Res., 2018; 12(9): ZD01-ZD02.

3. Song HF, Chen AZ, Wang SB, Kang YQ, Ye SF, Liu YG, Wu WG., Preparation of Chitosan-based hemostatic sponges by supercritical fluid technology. Materials, 2014; 7(4): 2459-2473. 
4. Liu JY, Li Y, Hu Y, Cheng G, Ye E, Shen C, Xu FJ, Hemostatic porous sponges of cross-linked hyaluronic acid/cationized dextran by one self-foaming process. Mater Sci Eng C Mater Biol Appl., 2018; 83: 160-168.

5. Kabiri M, Emami SH, Rafinia M, Tahriri M, Preparation and characterization of absorbable hemostat cross linked gelatin sponges for surgical applications. Curr Appl Phys., 2011; 11(3): 457-461.

6. Miguel SP, Ribeiro MP, Brancal H, Coutinho P, Correia IJ, Thermoresponsive chitosan-agarose hydrogel for skin regeneration. Carbohydr Polym., 2014; 111: 366-373.

7. O'Brien FJ, Harley BA, Yannas IV, The effect of pore size on cell adhesion in collagen-GAG scaffolds. Biomaterials, 2005; 26: 433-441.

8. Vons B, Tryhubchak O, Grochovuy T, Chubka M, Bihunyak V, Research of powders of the cryolyophilized xenoderm of porcine skin. Int J Green Pharm., 2018; 12(3); S657-S664.

9. Sun W, Chen Y, Yuan W, Hemostatic absorbable gelatin sponge loaded with 5-fluorouracil for treatment of tumors. Int J Nanomed., 2013; 8: 1499-506.
10. Peng YY, Glattauer V, Ramshaw JAM, Stabilisation of Collagen Sponges by Glutaraldehyde Vapour Crosslinking. Int J Biomater., 2017; 2017: 1-6.

11. Imani R, Rafienia M, Emami SH, Synthesis and characterization of glutaraldehyde-based crosslinked gelatin as a local hemostat sponge in surgery: an in vitro study. Biomed Mater Eng., 2013, 23(3): 211-224.

12. Pan Y, Shi K, Peng C, Wang W, Liu Z, Ji X, Evaluation of hydrophobic polyvinyl-alcohol formaldehyde sponges as absorbents for oil spill. ACS Applied Materials \& Interfaces, 2014; 6(11): 8651-8659.

13. Pan Y, Shi K, Liu Z, Wang W, Peng C, Ji X, Synthesis of new kind of macroporous polyvinyl-alcohol formaldehyde based sponges and its water superabsorption performance. RSC Adv., 2015; 5: 78780-78789.

14. Pavliuk BV, Chubka MB, Hroshovyi TA, The chromatographic determination of the chlorhexidine digluconate in the medical sponges (hemostatic sponges). Sciences of Europe, 2019; 1(44): 13-16.

15. Institute of Biomedical Technologies, www.ibt.in.ua. 